\title{
Call for Contributors to Fractography Handbook
}

\author{
Pierre Dupont · James F. Lane
}

Published online: 4 June 2019

(C) ASM International 2019

Currently, members of the Failure Analysis Society are collaborating with the Handbook Committee of ASM International to develop a new edition of ASM Handbook, Volume 12, Fractography. The current edition was last modified in 1987. That's more than 30 years ago-Think about the advances in technology and data collection since then. Think about how many fractographic images you've collected since then. Think of an atlas that has compiled all your fractographs and the fractographs of all of your colleagues for the past 30 years. That is the goal!

The editorial board for Volume 12 needs your help and contributions. We are seeking authors who can contribute

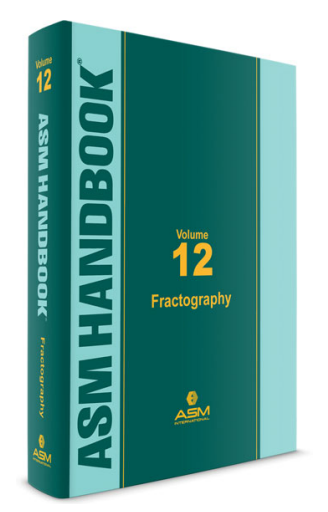

P. Dupont $(\bowtie)$

Schaeffler Belgium Sprl/bvba, Rue Du Commerce, NA-139,

7370 Dour, Belgium

e-mail: pierredupont@infonie.be

\section{J. F. Lane}

Rimkus Consulting Group, Inc., 7501 S. Quincy Street, Suite 160, Willowbrook, IL 60527, USA

e-mail: jameslane@bellsouth.net

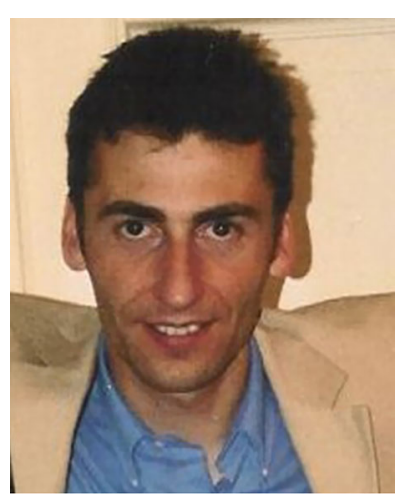
President ASM Failure Analysis Society
Pierre Dupont, P.E.

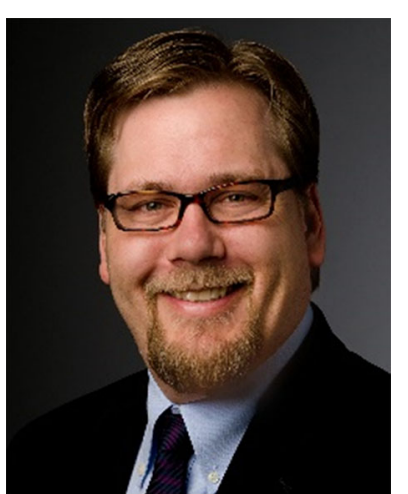

James F. Lane, P.E.

Vice President/President-Elect ASM Failure Analysis Society papers on the principles, practices, and applications of fractography in failure analysis and materials characterization. You can contribute through case histories of failures with fractographs illustrating fracture behavior, examination, and interpretation of metals, plastics, composites, ceramics, glasses, and electronic materials. We also need fractographs that show common, uncommon, and unusual fractures, so start compiling your images.

We need your help. We cannot accomplish this monumental task without you. Please consider participating in this endeavor. You can indicate your interest by sending an e-mail to Craig Schroeder, Chair of the Volume 12 Editorial Committee, at handbooks@asminternational.org. Again, please strongly consider participating in this endeavor. Thank you in advance for your support!

Publisher's Note Springer Nature remains neutral with regard to jurisdictional claims in published maps and institutional affiliations. 